\title{
古い鉄筋コンクリート柱の耐震性に及ぼす袖壁の影響 EFFECT OF SIDE WALLS ON SEISMIC PERFORMANCE OF OLD RC COLUMNS
}

\author{
金 紅 日*, 芳村 学**, 中村孝也***, 保木和 明* \\ Hongri JIN, Manabu YOSHIMURA, Takaya NAKAMURA \\ and Kazuaki HOKI
}

\begin{abstract}
This study is intended to get an answer to the question that the adding of side walls to old RC columns is effective to enhance their seismic performance or not. For this purpose, ten half-scale model specimens simulating columns designed by the pre-1971 codes with/without side walls were tested until they collapsed. The tests revealed the side-wall adding increased lateral strength but decreased deformability. Then the earthquake response analyses were conducted for three-story model buildings consisting of the tested columns with/without side walls, where the observed load-deflection relations until collapse were used. The side-wall adding was judged as "advantageous" if the ratio of maximum response drift to drift at collapse became smaller than that of the case without side walls. The side-wall adding was "advantageous" in most examples.
\end{abstract}

Keywords: reinforced concrete column, side wall, collapse, earthquake response analysis, seismic performance 鉄筋コンクリート柱, 袖壁, 崩壊, 応答解析, 而震性能

\section{1. はじめに}

古いRC造中低層集合住宅（その長辺方向）の柱には，袖壁，腰壁 などの二次壁が取り付くことが多い。古い集合住宅は大地震時に倒 壊など大きな被害を受ける可能性があるので，その耐震性評価にお いては, 二次壁が付いた状態での柱の構造性能を, 大変形時まで, できれば軸力保持能力嘔失（崩壊）に至るまで，を考慮に入れた形 で把握しておくことが重要となる。

腰壁付加は, 柱の剛性と強度を高める反面, 短柱化による変形能 力の低下があまりに大きく, 柱の耐震性を低下させることは言うま でもない。他方, 袖壁付加については, 柱の剛性と強度を高める反 面変形能力を低下させる点では腰壁付加と同じであるが，柱の而震 性に対する両者の影響度合いについては, よくわかっていない例えば1) ６)。また，袖壁付き柱の剛性と強度の組み合わせを種々変化させた 骨組漸増載荷解析からも, 袖壁付加には骨組の耐震性を向上させる 場合と低下させる場合があることが報告されている7)。このように, 袖壁付加が柱の耐震性に有利なのか不利なのかについては，よくわ からないというのが実情である。本研究は，この問題に一応の答え を出すことを第一の目的としている（注 1）。もし腰壁付加が有利
となれば，耐震補強において袖壁の増設が推奨されることになり， 逆に不利となれば，それは薦められない，あるいは既存の袖壁付き 柱に対してはスリットを挿入することが薦められることになる。

上記目的のため，1971年以前の中低層集合住宅の一階を対象とし た, 袖壁付き柱及び袖壁なし柱の崩壊実験を行う ${ }^{8)}$ 。袖壁付き柱の 崩壊までの実験は過去に行われていない。まず，過去の研究になら って, 袖壁の有無による最大強度や変形能力 (ここでは崩壊変形), 等の変化度合に着目して，袖壁付加の有利，不利について論じる。 ついで，実験結果に基づく崩壊までの荷重変形関係を用いた地震応 答解析により，この問題に対するより定量的な評価を試みる。

ところで，袖壁付き柱のせん断強度算定式には，断面を等価な長 方形断面に置換する荒川式系統の式 (Qsu2 式) ${ }^{9)}$ と，柱にトラス・ アーチ機構, さらに袖壁にもアーチ機構を考慮した, 大宮らによる 式10) がある。しかしどちらにおいても, 集合住宅長辺方向の北面に 多い, せいのごく短い（シヤースパン比が1以下となる）柱に対する 式の精度は論じられていない。そこで本研究では, 耐震診断で広く 用いられている $\mathrm{QSU}_{\mathrm{Su}}$ 式の方を用いて, シヤースパン比が1以下となる 場合に対寸る適用性について検討寸る。
* 東京都立大学大学院工学研究科建築学専攻 大学院生・修士 (工学)

** 首都大学東京大学院都市環境科学研究科建築学専攻 教授. 工博

*** 首都大学東京大学院都市環境科学研究科建築学専攻 助教・博士 (工学)
Graduate Student, Department of Architecture, Graduate School of Engineering, Tokyo Metropolitan University, M. Eng.

Prof., Graduate School of Architecture and Building Engineering, Tokyo Metropolitan University, Dr. Eng.

Assistant Prof., Graduate School of Architecture and Building Engineering, Tokyo Metropolitan University, Dr. Eng. 


\section{2. 実験概要}

\section{1 試験体}

試験体諸元一覧を表 1 に, 材料特性を表 2 に, 試験体概要を図 1 に示 す。試験体は両端固定形式の柱であり，実柱の約 $1 / 2$ のサイズとし た。1971年以前の建物では主筋・横補強筋ともに丸鋼を用いた場合 が多いことから，本試験体でも丸鋼を使用した。コンクリートは設 計基準強度 $18 \mathrm{~N} / \mathrm{mm}^{2}$ 程度のものを想定した。試験体のコンクリート 実強度は $26.9 \mathrm{~N} / \mathrm{mm}^{2}$ となった。また, 集合住宅の短辺方向は耐震壁 構造とする場合が多いことから,す心゙ての試験体に直交壁を付けた。 直交壁はねじれの影響が生じないよう対称配置とし，その長さは加 力装置に設置可能な上限とした。

実験パラメータは袖壁の付き方と $\mathrm{h}_{0} / \mathrm{D}$ (クリアスパン比, ここで, hoはクリアスパン，Dは柱のみのせい）である。袖壁の付き方は3種 類とした。すなわち，袖壁なしのC0シリーズ（3体），片側袖壁付 きのC1シリーズ (4体)，両側袖壁付きのC2シリーズ (3体) の, 計 10 体である。 $\mathrm{h}_{0} / \mathrm{D}$ は $1.5,2.5,3.5,5.5$ の 4 種類とした。

全試験体の共通因子は以下のとおりである。柱断面寸法 : $\mathrm{b} \times \mathrm{D}=$ $250 \times 300 \mathrm{~mm}$, 主筋比 : $\mathrm{p}_{\mathrm{g}}=1.59 \%(8-13 \phi, 2-9 \phi)$, 横補強筋比 : $\mathrm{p}_{\mathrm{w}}$ $=0.10 \%(4 \phi @ 100)$, 柱のみの面積に対する軸力比 : $\eta=\mathrm{N} /\left(\mathrm{bD} \sigma_{\mathrm{B}}\right)$

表 1 試験体諸元一覧

\begin{tabular}{|c|c|c|c|c|}
\hline \multirow{2}{*}{$\begin{array}{l}\text { 試験 } \\
\text { 体名 }\end{array}$} & \multirow[b]{2}{*}{$\mathrm{h}_{0} / \mathrm{D}$} & \multirow{2}{*}{$\begin{array}{c}\mathrm{h}_{0} \\
(\mathrm{~mm})\end{array}$} & \multicolumn{2}{|c|}{ 袖壁 } \\
\hline & & & $\begin{array}{c}\text { 断面 } \mathrm{t} \times \mathrm{L}_{\mathrm{w}} \\
(\mathrm{mm})\end{array}$ & $\begin{array}{c}\text { 鉄筋比 } \\
(\%)\end{array}$ \\
\hline $\mathrm{C} 0-15$ & 1.5 & 450 & \multicolumn{2}{|c|}{ なし } \\
\hline $\mathrm{C} 0-25$ & 2.5 & 750 & \multicolumn{2}{|c|}{ なし } \\
\hline $\mathrm{C} 0-35$ & 3.5 & 1050 & \multicolumn{2}{|c|}{ なし } \\
\hline $\mathrm{C} 1-15$ & 1.5 & 450 & \multirow{4}{*}{$\begin{array}{c}60 \times 300 \\
{[\times 1]}\end{array}$} & \multirow{4}{*}{$\begin{array}{c}0.22 \\
{[4 \phi @ 100]}\end{array}$} \\
\hline $\mathrm{C} 1-25$ & 2.5 & 750 & & \\
\hline C1-35 & 3.5 & 1050 & & \\
\hline C1-55 & 5.5 & 1650 & & \\
\hline C2-25 & 2.5 & 750 & \multirow{3}{*}{$\begin{array}{c}60 \times 300 \\
{[\times 2]}\end{array}$} & \multirow{3}{*}{$\begin{array}{c}0.22 \\
{[4 \phi @ 100]}\end{array}$} \\
\hline $\mathrm{C} 2-35$ & 3.5 & 1050 & & \\
\hline C2-55 & 5.5 & 1650 & & \\
\hline
\end{tabular}

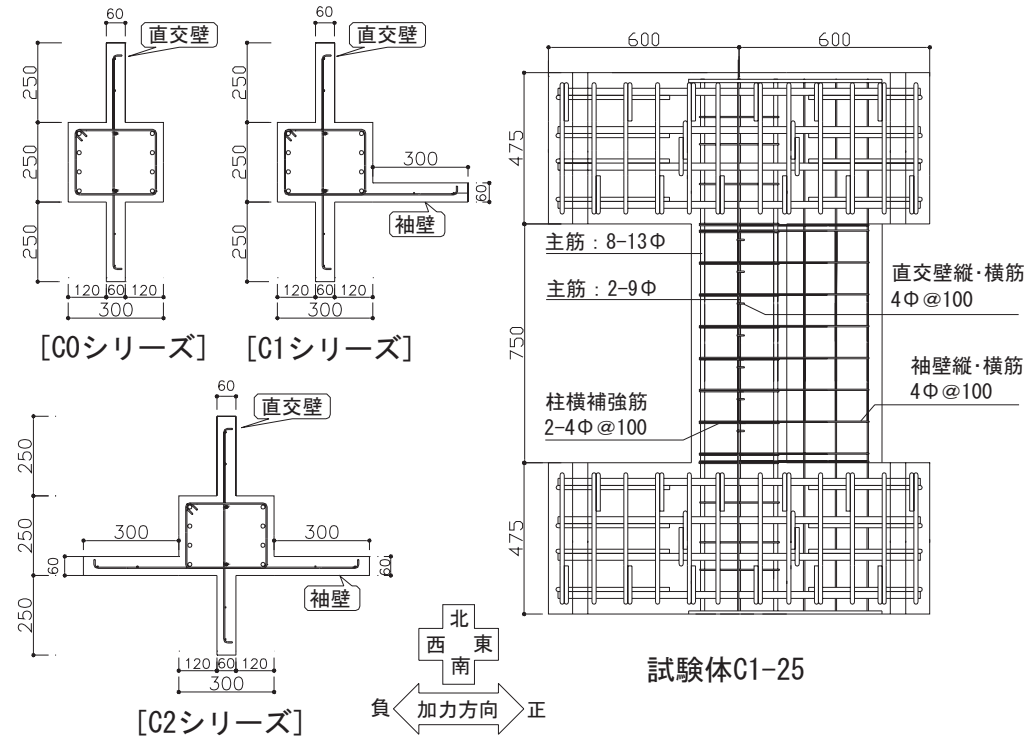

図 1 試験体概要 (単位: $\mathrm{mm}$ )
表 2 材料特性

(a) 鉄筋

\begin{tabular}{c|c|c|c}
\hline 呼び名 & $\begin{array}{c}\text { 降伏強度 } \\
\left(\mathrm{N} / \mathrm{mm}^{2}\right)\end{array}$ & $\begin{array}{c}\text { 降伏歪 } \\
(\%)\end{array}$ & $\begin{array}{c}\text { ヤング係数 } \\
\left(\mathrm{N} / \mathrm{mm}^{2}\right)\end{array}$ \\
\hline $4 \phi$ & 258 & 0.128 & $1.99 \times 10^{5}$ \\
\hline $9 \phi$ & 362 & 0.191 & $1.93 \times 10^{5}$ \\
\hline $13 \phi$ & 349 & 0.173 & $1.87 \times 10^{5}$ \\
\hline
\end{tabular}

(b) コンクリート

\begin{tabular}{c|c|c}
\hline $\begin{array}{c}\text { 圧縮強度 } \\
\left(\mathrm{N} / \mathrm{mm}^{2}\right)\end{array}$ & $\begin{array}{c}\text { 圧縮強度時歪 } \\
(\%)\end{array}$ & $\begin{array}{c}\text { ヤング係数 } \\
\left(\mathrm{N} / \mathrm{mm}^{2}\right)\end{array}$ \\
\hline 26.9 & 0.190 & $2.01 \times 10^{4}$ \\
\hline
\end{tabular}

$=0.17\left(\mathrm{~N}\right.$ : 軸力, $\sigma_{\mathrm{B}}$ : コンクリート強度 $)$, 直交壁断面 : $\mathrm{t} \times \mathrm{L}_{\mathrm{w}}$ $=60 \times 250 \mathrm{~mm}[\times 2]$, 直交壁筋比 $=0.22 \%(4 \phi @ 100)$ 。また, 片側袖壁 断面 : $\mathrm{t} \times \mathrm{L}_{\mathrm{w}}=60 \times 300 \mathrm{~mm}$, 袖壁筋比=0.22\%（4 $\phi$ @ 100）である。

\section{2 加力概要}

加力には，パンタグラフにより上下スタブの平行が保持される逆 対称加力装置を用いた ${ }^{8)}$ 。加力は一定軸力下での水平方向正負交番 載荷とした。載荷履歴は部材角（水平変形をクリアスパンで除した 值） $\pm 0.5 \%, \pm 1.0 \%, \pm 2.0 \%$ の加力を各一回行った後, 軸力保持能力 を喪失して鉛直方向に崩壊するまで, あるいは加力装置の限界まで 押し切った。

\section{3. 実験結果}

\section{1 破壊過程}

試験体の破壞状況の例を写真1に, 正加力時包絡線およびのちの解 析に用いるスケルトンカーブを図 2 に, 実験結果および終局強度計算 值一覧を表3に示す。図 2 で層間変形角は, 後述する実建物のイメー ジ（図 $8, \mathrm{~h}_{0} / \mathrm{D}=2.5$ の場合）に基づいて，建物としての階高 $3600 \mathrm{~mm}$ と1/2模型としての試験体のクリアスパン $\mathrm{h}_{0}$ を考慮して, 部材角から

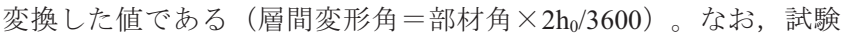
体C0-35, C1-55, C2-55は加力装置の限界まで加力を行ったが，崩壊 しなかった。また， C0-15 とC2-55では最大強度が負加力時に生じた が，崩壊が生じた方向を重視して，正加力時包絡線を示した。

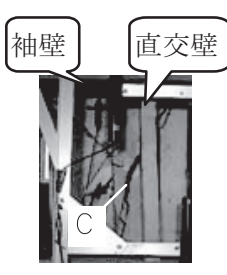

崩壊時 (北側)

C1-25

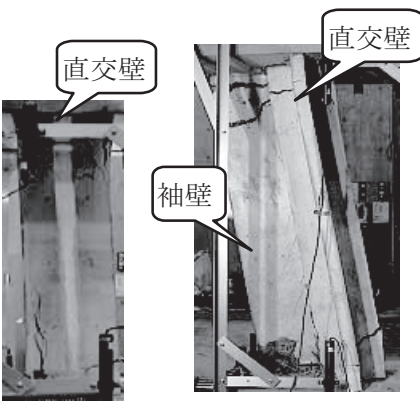

実験終了時（北側）

C1-55

\section{a せん断破壊}

\section{b 付着破壊}

写真 1 試験体の破壊状況 
実験の結果，破壊モードはせん断破壞または付着破壊となり，曲 げ破壊したものはなかった。主筋に異形鉄筋を用いると曲げ破壊す
る場合でも，主筋に丸鋼を用いると，付着劣化により主筋が降伏せ ずに曲げ破壊しない場合があることが指摘されており ${ }^{11)}$, 本実験に

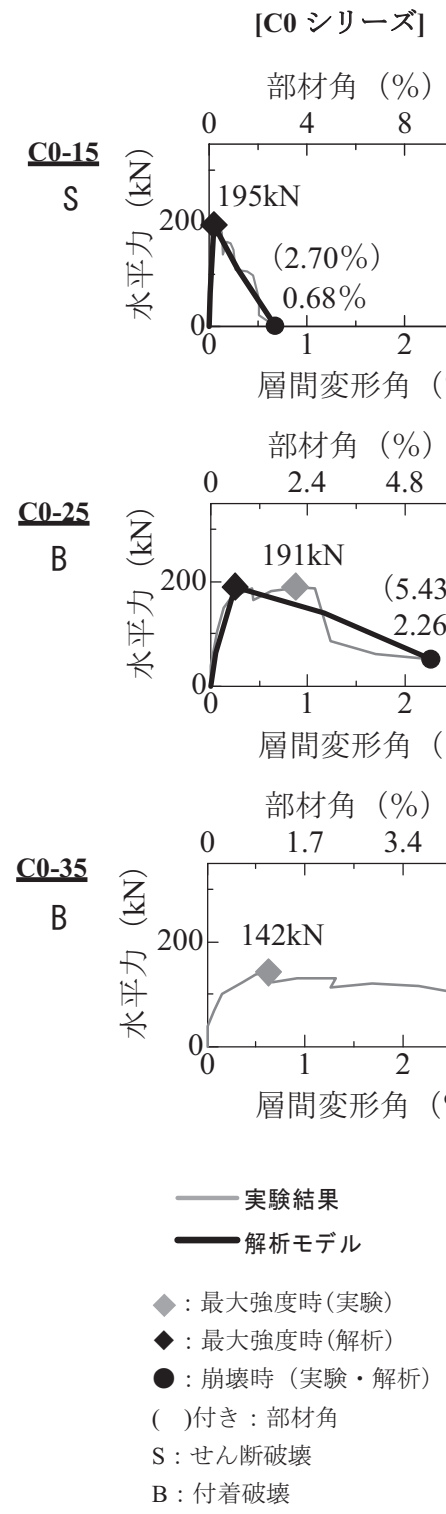

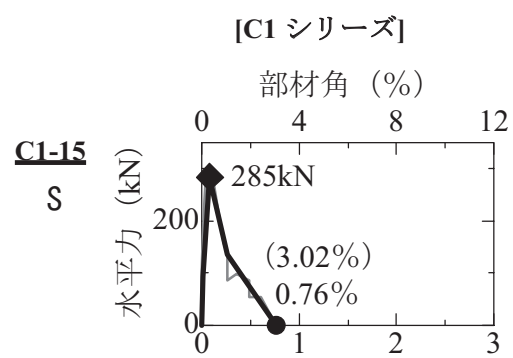

層間変形角 $(\%)$

部材角 $(\%)$

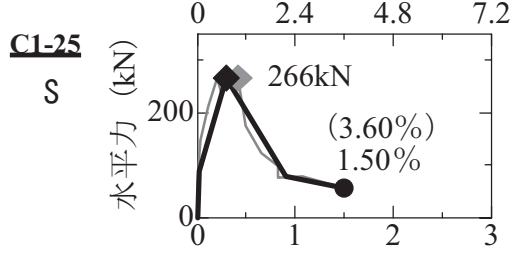

層間変形角 $(\%)$

部材角 $(\%)$

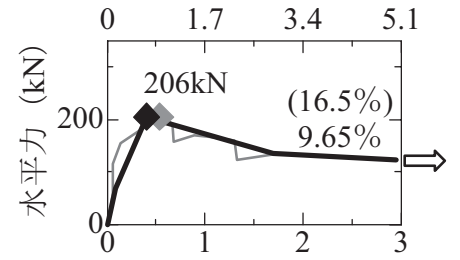

層間変形角 $(\%)$

部材角 $(\%)$

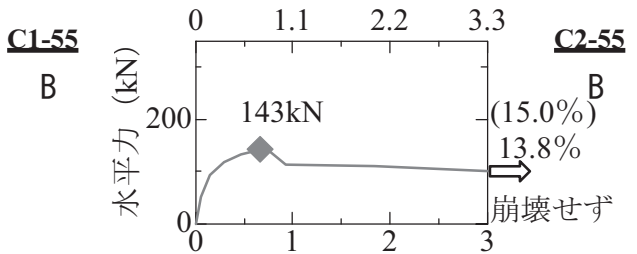

層間変形角 $(\%)$
[C2 シリーズ]

部材角 $(\%)$

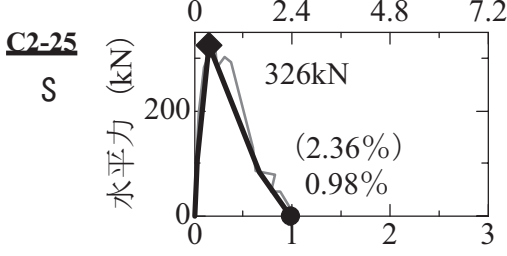

層間変形角 $(\%)$

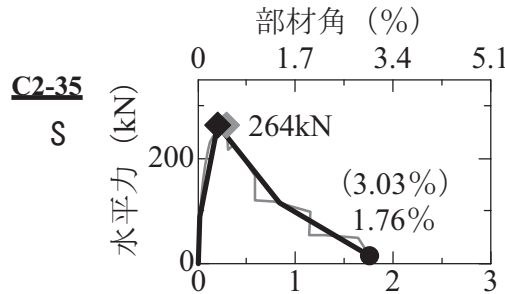

層間変形角 $(\%)$

部材角 $(\%)$

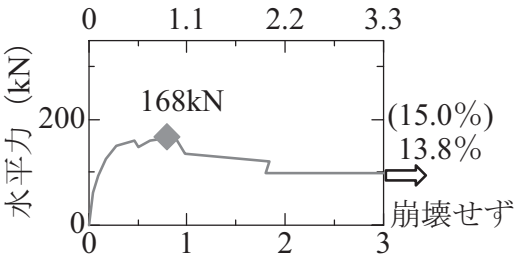

層間変形角 $(\%)$

図 2 正加力時包絡線と仮定したスケルトンカーブ

表 3 実験結果および終局強度計算值一覧

\begin{tabular}{|c|c|c|c|c|c|c|c|c|c|}
\hline \multirow{2}{*}{$\begin{array}{l}\text { 試験 } \\
\text { 体名 }\end{array}$} & \multirow{2}{*}{$\begin{array}{l}\text { 破壊 } \\
\text { モード }\end{array}$} & \multirow{2}{*}{$\begin{array}{c}\text { 最大強度 } \\
\text { 実験值 } \\
(\mathrm{kN})\end{array}$} & \multirow{2}{*}{$\mathrm{M} /\left(\mathrm{Q} \cdot \mathrm{d}_{\mathrm{e}}\right)^{* 1}$} & \multicolumn{2}{|c|}{ せん断終局強度(kN) } & \multicolumn{2}{|c|}{ 曲げ終局強度(kN) } & \multirow{2}{*}{$\begin{array}{l}\text { 最大強度時 } \\
\text { 部材角( } \%)\end{array}$} & \multirow{2}{*}{$\begin{array}{c}\text { 崩壊部材角 } \\
(\%)\end{array}$} \\
\hline & & & & 計算值 & 実/計 & 計算值 & 実/計 & & \\
\hline $\mathrm{C} 0-15$ & せん断 & -201 & \multirow{3}{*}{-} & 191 & 1.05 & 383 & 0.52 & -0.51 & 2.70 \\
\hline $\mathrm{C} 0-25$ & 付着 & 191 & & 167 & 1.14 & 230 & 0.83 & 1.85 & 5.43 \\
\hline $\mathrm{C} 0-35$ & 付着 & 142 & & 138 & 1.03 & 164 & 0.87 & 0.96 & {$[24.0]^{* 3}$} \\
\hline $\mathrm{C} 1-15$ & せん断 & 285 & 0.38 & $189[253]^{* 2}$ & $1.51[1.13]$ & 574 & 0.50 & 0.31 & 3.02 \\
\hline $\mathrm{C} 1-25$ & せん断 & 266 & 0.63 & $189[247]$ & $1.41[1.08]$ & 345 & 0.77 & 1.00 & 3.60 \\
\hline C1-35 & 付着 & 206 & 0.88 & $189[202]$ & $1.09[1.02]$ & 246 & 0.84 & 0.82 & 16.5 \\
\hline $\mathrm{C} 1-55$ & 付着 & 143 & 1.38 & $157[157]$ & $0.91[0.91]$ & 157 & 0.91 & 0.72 & {$[15.0]$} \\
\hline $\mathrm{C} 2-25$ & せん断 & 326 & 0.42 & $194[258]$ & $1.68[1.26]$ & 456 & 0.71 & 0.45 & 2.36 \\
\hline $\mathrm{C} 2-35$ & せん断 & 264 & 0.58 & $194[258]$ & $1.36[1.02]$ & 326 & 0.81 & 0.49 & 3.03 \\
\hline $\mathrm{C} 2-55$ & 付着 & -196 & 0.92 & $194[203]$ & $1.01[0.97]$ & 207 & 0.95 & -1.00 & {$[15.0]$} \\
\hline
\end{tabular}

*1 3.2 節参照。*2 [ ] 付きは $\mathrm{M} /\left(\mathrm{Q} ・ \mathrm{~d}_{\mathrm{e}}\right)$ の下限值 1 を 0.6 に読み替えた場合の值。*3 [ ] 付きは実験終了時の值。 
おいても同様の結果となった。以下, 破壊過程を破壊モード毎に記 述する（破壊モードは表3参照）。

せん断破壊した試験体（C0-15, C1-15, C1-25，C2-25, C2-35）

袖壁が付かない柱 (C0-15) : 柱全長に渡るせん断ひび割れが生じ,

そのひび割れが崩壊に至るまで広がった。

袖壁が付く柱（C1-15，C1-25，C2-25，C2-35）：最初に袖壁にせ し断ひび割れが発生し, それが進展して柱のせん断ひび割れとなっ た。しかしその後, すべての試験体で柱部分のみに入るせん断ひび 割れが別途発生し, そのひび割れが崩壊に至るまで広がった(写真1a にCで示す）。

付着破壊した試験体（C0-25, C0-35, C1-35, C1-55, C2-55）

袖壁が付かない柱（C0-25, C0-35）：最初に柱端部に曲げひび割 れが発生した。最大強度前後に柱端部のコンクリートの圧壊が始ま り, 変形の増加とともに圧壊が進行した。C0-35では部材角 $3 \%$ 程度 から柱端部に付着破壊による縦方向のひび割れが見られた（写真 $1 \mathrm{~b}$ のC0-35）。一方，C0-25ではこのような縦方向のひび割れは見られ なかった。

袖壁が付く柱（C1-35, C1-55, C2-55）：最初に袖壁にせん断ひび 割れと曲げひび割れが発生し，その後それらが柱に進展した。変形 の増加とともにこの曲げひび割れの幅が広がったが, せん断ひび割 れの幅は広がらなかった。袖壁1枚の試験体（C1-35とC1-55）では, 最大強度前後に柱と袖壁端部のコンクリートの圧壊が始まり, 変形 の増加とともに圧壊が進行した（写真1bのC1-55）。袖壁2枚の試験 体（C2-55）では，上下の袖壁端部でコンクリートの圧壊が生じ, 変 形の増加とともに圧壊が進行した。

なお，この付着破壊については3.3節で改めて検討する。

\section{2 袖壁付き柱のせん断強度について}

袖壁付き柱のせん断強度を文献9）における提案式（Q $\mathrm{su2}$ 式）によ り求めた（図3参照）。ここで，Qsu2式は直交壁の影響を考慮してい ないので, 計算においては直交壁を無視した。 $1 \leqq \mathrm{M} /\left(\mathrm{Q} \cdot \mathrm{d}_{\mathrm{e}}\right)=\mathrm{h}_{0} /(2 \mathrm{~L})$ $\leqq 2$ とされることに注意されたい。計算結果を表 3 に示す。なお，表 3 における柱のみのC0シリーズのせん断強度は，直交壁の影響を考慮 した壁柱のせん断終局強度式（HFW指針） ${ }^{12)}$ により求めたが，本節 での検討の対象ではない。

せん断破壊した袖壁付き柱の試験体では, 表3に示すように, 計算 值は $\mathrm{M} /\left(\mathrm{Q} \cdot \mathrm{d}_{\mathrm{e}}\right)$ （以下，シヤースパン比）の下限值1の制限を受けて

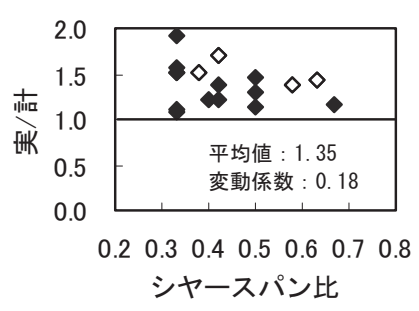

(a)シヤースパン比の下限值 $=$

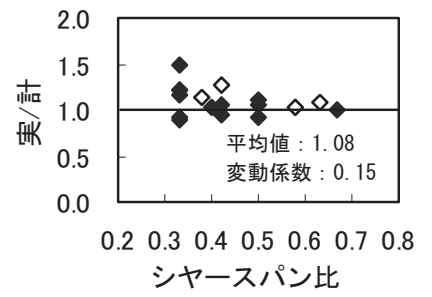

図 4 せん断強度に対するシヤースパン比の影響

一定值となるが（C1-15 とC1-25，およびC2-25とC2-35で），実験で はシヤースパン比が小さいほど最大強度が増加している。その結果, 部材の高さが小さいほど実験值/計算値の值が1より大きくなってい く。そこで，以下ではこの下限值に関する検討を行う。

既往の袖壁付き柱試験体13体の結果 3), 4),5), 13)を用いて検討する。こ れらには直交壁が付いていないため, 直交壁が付いた本実験の試験 体に比べてQ $\mathrm{Su}_{\mathrm{Su}}$ 式との対応の検討に適していると考えられるからで ある。シヤースパン比と実験值/計算值の関係を図4(a)にいで示す。 シヤースパン比の下限值を1とした場合, シヤースパン比が小さいほ ど実験值/計算值の值が大きくなっているため, 実験值/計算值の平 均值は 1.35 , 変動係数は 0.18 と, 平均值, バラッキともに大きい。 つまり, Q $\mathrm{QS}_{2}$ の計算においてシヤースパン比の下限值 1 をげたほう が計算值が実験值に近づくことが予想される。そこで，シヤースパ ン比の下限值1を0.6にすると, 図4(b)に示すように, 実験値/計算值 の平均值は 1.08 , 変動係数は 0.15 となり, 平均值, バラツキともに 下限值1の場合に比べて改善された。参考のため, 本実験においてせ ん断破壊した袖壁付き柱試験体4体に対して同様の検討を行った結 果を, 図4につで示す。これらも同様にシヤースパン比の下限值を 0.6 にすることによって計算精度が改善されている。

以上, シヤースパン比の下限值を 0.6 とする, やや危険側の評価 となる場合もみられるが（図4(b)）, 全般的に見て計算精度が改善

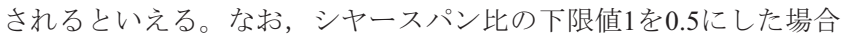
も検討したが, その場合, 実験值/計算值の平均值は 0.98 , 変動係数 は 0.14 となり，下限值1を 0.6 とした場合より危険側の評価が多くみ られた。このことから，下限值1を0.6とした場合のほうが妥当と判 断した。

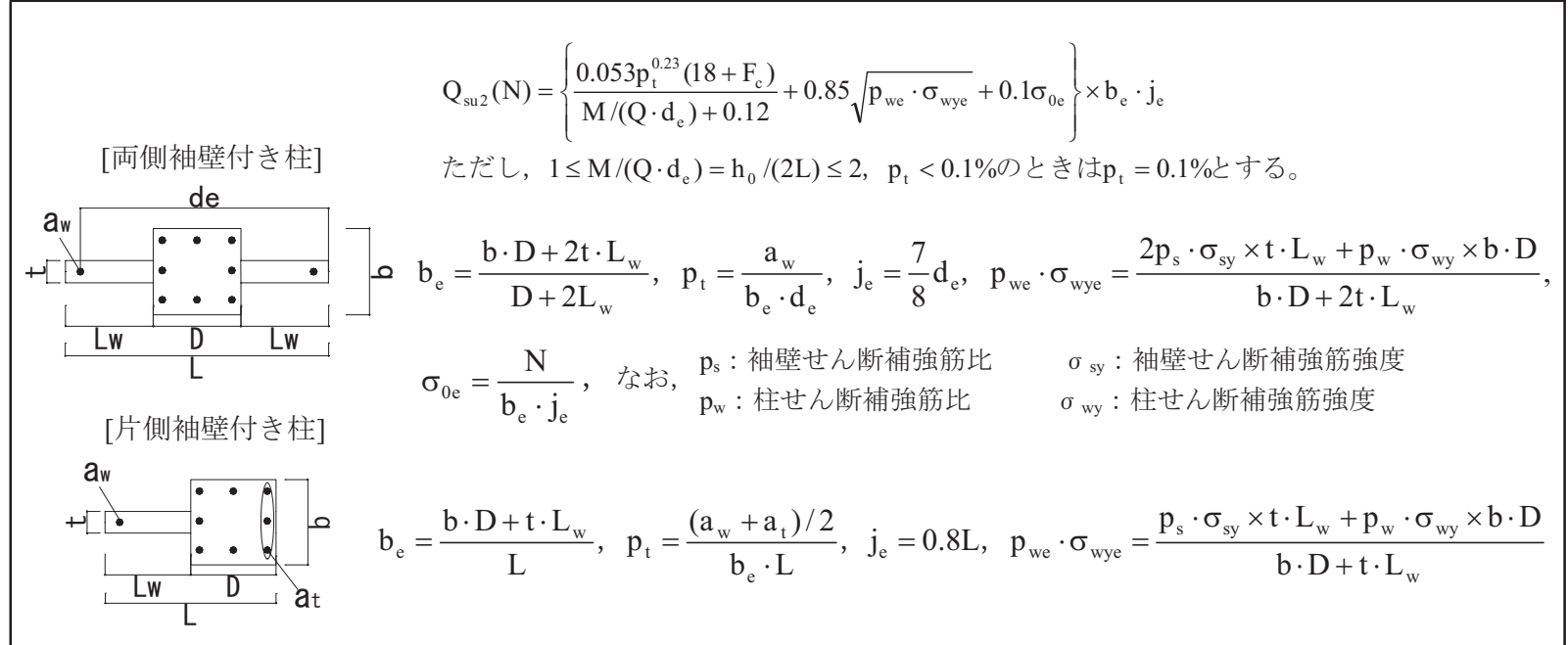

図 3 袖壁付き柱のせん断終局強度の計算式 


\section{3 付着破壊について}

筆者らの過去の文献8）では，試験体C0-25, C0-35などを荷重変形 関係から曲げ破壊と記したが，実際には崩壊まで柱の主筋は降伏し ていなかった。

例としてC0-25とC0-35の各部材角における主筋の歪分布を図5に 示す。初期段階での歪挙動は, 柱脚で圧縮, 柱頭で引張の逆対称分 布であるが，部材角の増加とともに柱脚が引張に変化して柱頭と同 程度の值となっている。このことから付着劣化が生じたことがわか る。

なお, 表3における実験值と計算值の比較では, 袖壁の有無に関わ らず，付着破壊した試験体の強度は曲げ強度計算值（ファイバーモ デルにより求めた）より $10 \%$ 程度（9～17\%）低かった。過去の, 丸 鋼あるいはアンボンド鉄筋を主筋とした柱の実験研究でも, 付着破 壞が生じると実験值は計算上の曲げ強度に達しないことが報告され ている ${ }^{14), 15)}$

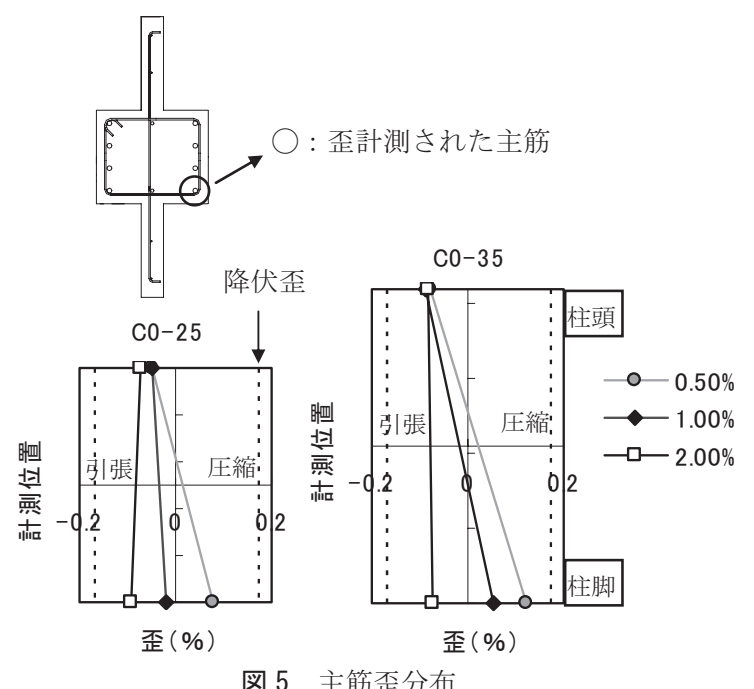

\section{4. 袖壁の影響}

\section{1 実験結果による袖壁の影響評価}

破壊モード, 最大強度（正負での大きい方）, 最大強度時変形（部 材角), 崩壊変形 (部材角) に対する袖壁の影響を図6に示す。以下, 袖壁の影響について，各項目に分けて述べる。ここで， $\mathrm{h}_{0} / \mathrm{D}$ は袖壁 のない柱と袖壁付き柱に対して共通の尺度（クリアスパン $\mathrm{h}_{0}$ に応じ て一義的に定まる）であるので， $\mathrm{h}_{0} / \mathrm{D}$ 毎に区分する。

1) 破壊モード : $\mathrm{h}_{0} / \mathrm{D}=1.5$ では全てせん断破壊，同5.5では全て付 着破壞となり，同一 $\mathrm{h}_{0} / \mathrm{D}$ では破壞モードは変わらなかった。し かし， $\mathrm{h}_{0} / \mathrm{D}=2.5$ と 3.5 では袖壁が付くことにより付着破壊から せん断破壊に移行した。

2）最大強度： $\mathrm{h}_{0} / \mathrm{D}$ の值によらず，袖壁が一枚付くと最大強度が同 程度 $(64 \sim 90 \mathrm{kN})$ 増加し, 二枚付くとさらに同程度最大強度が 増加した $(53 \sim 60 \mathrm{kN})$ 。

3) 最大強度時変形 : $\mathrm{h}_{0} / \mathrm{D}=1.5,2.5,3.5$ では, 袖壁枚数が多いほ ど最大強度時変形が小さくなった。これは, 袖壁が増えるほど 付着破壊からせん断破壊になりや寸く, 小さい変形の段階で最 大強度に達したためである。 $\mathrm{h}_{0} / \mathrm{D}=5.5$ では逆の傾向を示したが， どちらも付着破壊であったことが関係していると思われる。
4) 崩壊変形: $\mathrm{h}_{0} / \mathrm{D}=2.5$ と 3.5 では, 袖壁枚数が多いほど崩壊変形 が小さくなった。特に $\mathrm{h}_{0} / \mathrm{D}=3.5$ では, 崩壊変形の低下が顕著で あった。一方, $\mathrm{h}_{0} / \mathrm{D}=1.5$ では, 袖壁付加によって崩壊変形がわ ずかではあるが増加した。なお， $\mathrm{h}_{0} / \mathrm{D}=5.5$ では, 加力装置の限

界まで加力したが崩壊しなかったので，以上の検討はできない。 上記4項目のうち, 最大強度と崩壊変形が柱の耐震性に対して特に 重要であるため, これらの変化度合に着目寸る。 $\mathrm{h}_{0} / \mathrm{D}=1.5$ の場合, 袖壁付加によって最大強度と崩壊変形がともに増加したので, 袖壁 付加は明らかに有利である。 $\mathrm{h}_{0} / \mathrm{D}=2.5$ の場合, 袖壁枚数が多いほど 最大強度が増加寸る一方で崩壊変形は低下したため, 有利か不利か を判断することは難しい。 $\mathrm{h}_{0} / \mathrm{D}=3.5$ の場合, 袖壁付加による最大強 度の増加よりも崩壊変形の低下がはるかに大きいため, 袖壁付加は 不利なように見える（特にC1-35 とC2-35の比較）。 $\mathrm{h}_{0} / \mathrm{D}=5.5$ の場合， 崩壊変形は不明であるが，十分に大きな変形まで崩壊しなかったた め, 最大強度が増加した分袖壁付加は有利と思われる。

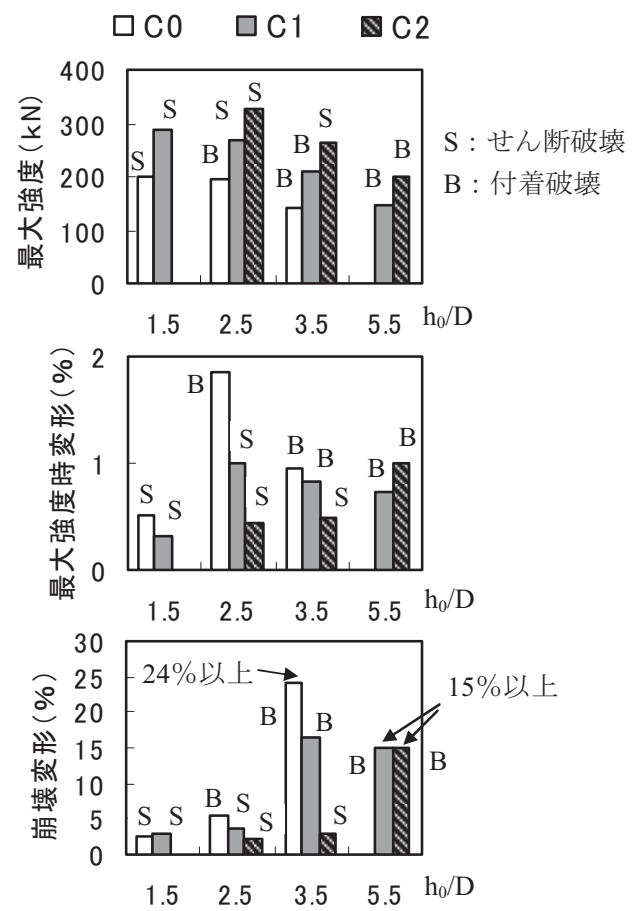

図 6 破壊モード，最大強度と変形能に対する袖壁の影響

\section{2 地震応答解析による袖壁の影響評価} 建物のモデル化

以上の結果を総合すると, 袖壁が付くことによる最大強度の増加 度合は同程度であるのに対し, 崩壊変形の低下度合は様々であった。 つまり, 実験結果のみから袖壁付加の有利・不利について判断する ことは困難であるといえる。そこで以下，実験結果に基づくモデル 建物についての地震応答解析を行い, これにより袖壁の影響を評価 することを試みる。

解析モデルを図7に示す。旧基準によるRC造3層建物を想定したせ ん断型モデルである。各層一種類の柱からなるとし, 各層階高を $3600 \mathrm{~mm}$ ，各層重量を $753 \mathrm{kN}$ と仮定した ${ }^{16)}$ 。

一例として, $\mathrm{h}_{0} / \mathrm{D}=2.5$ の場合の解析モデルの概要を以下に示寸。

1) 実建物のイメージを図8に示す。モデルC0は袖壁なしの柱，モ デルC1は片側袖壁付き柱, モデル 22 は両側袖壁付き柱からな 


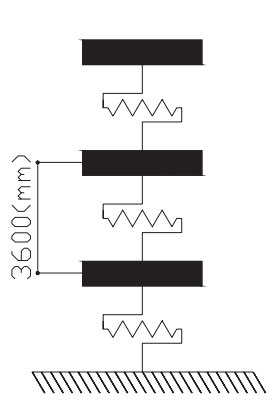

図 7 モデル建物

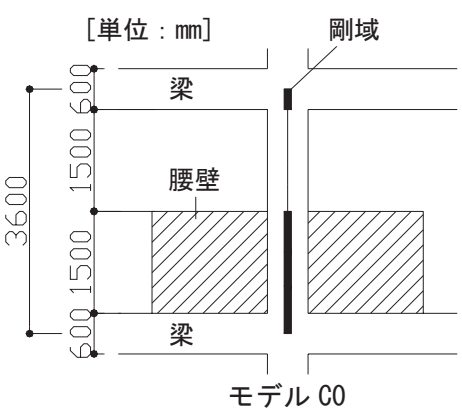

図 8

る建物である。各柱は試験体の 2 倍のサイズであり, それぞれ C0-25，C1-25，C2-25試験体に対応している。

2) 3層程度の建物では柱断面を同一とすることが多いことから, 各層の初期剛性, 最大強度は同一とした。

3) モデル 0 の一次固有周期を 0.216 (建物高さ $[\mathrm{m}] \times 0.02)$ 秒として そのときの初期剛性を求めた。モデル C1 とモデルC2 2゙は袖壁 付加による初期剛性の増加を考虑して, 袖壁を含む柱の断面積 （ただし, 直交壁は除く）が増加する比率をモデル $\mathrm{C} 0$ の初期剛 性に乗ずることにより初期剛性を定めた。結果としてモデルC1 では0.145秒，モデルC2では0.133秒となった。

4) モデルC 0 の層のC值を 0.4 とした。モデル $\mathrm{C} 1$ とモデル $\mathrm{C} 2$ では袖 壁付加による強度の増加を実験結果（図2）の比率に合わせて 定めた。1層のC值は, モデルC1では0.56 (モデルC0の1.40倍), モデルC2では0.68（同1.70倍）となった。

\section{実験結果のモデル化}

荷重変形関係のスケルトンカーブは, 文献16)の方法を基本として 以下のように定めた。このとき, 全ての試験体で正方向の包絡線に 合わせた。崩壊しなかった試験体を除くスケルトンカーブを図 2 に示 す。

1) 第1折れ点強度は第2折れ点強度（最大強度）の1/3とした。こ れにより, 第1 折れ点変形は第1折れ点強度と初期岡性から定ま る。

2) 第2折れ点強度は前項4)のルールにより定まる。また，第2折れ 点変形は, 実験結果と概初対応させた。

3）第2折れ点と第4折れ点（崩壊点）の間に第3折れ点を設け，第2 折れ点以降崩壊までの挙動を表現した。第3折れ点の変形と強 度は実験結果に基づいて適宜定めた。このとき, せん断破壞し た柱では第2折れ点以降荷重が急激に低下寸るが，付着破壊し た柱では荷重が緩やかに低下寸ることを表した。

4) 第4折れ点の変形とそのときの強度は実験結果と同じとした。

表 4 各モデルの 4 折れ点

\begin{tabular}{|c|c|c|c|c|c|c|c|}
\hline 名 & \begin{tabular}{|c|} 
第1折れ点 \\
層間変形角 \\
$(\%)$ \\
\end{tabular} & \begin{tabular}{|c|} 
第2折れ点 \\
層間変形角 \\
$(\%)$ \\
\end{tabular} & \begin{tabular}{|c|} 
第3折れ点 \\
層間変形角 \\
$(\%)$ \\
\end{tabular} & \begin{tabular}{|c|} 
第4折れ点 \\
層間変形角 \\
$(\%)$ \\
\end{tabular} & C值 & \begin{tabular}{|c} 
第3折れ点 \\
強度/最大 \\
強度 $(\%)$ \\
\end{tabular} & $\begin{array}{c}\text { 第4折れ点 } \\
\text { 強度/最大 } \\
\text { 強度 }(\%) \\
\end{array}$ \\
\hline C0-15 & 0.009 & 0.051 & 0.292 & 0.680 & 0.4 & \begin{tabular}{|l|}
57 \\
\end{tabular} & 0 \\
\hline C1-15 & 0.008 & 0.077 & 0.262 & 0.760 & $0.4 \times 1.46$ & 48 & 0 \\
\hline $\mathrm{C} 0-25$ & 0.050 & 0.250 & 1.171 & 2.260 & 0.4 & 73 & 28 \\
\hline C1-25 & 0.020 & 0.300 & 0.890 & 1.500 & $0.4 \times 1.40$ & 30 & 21 \\
\hline C2-25 & 0.030 & 0.180 & 0.658 & 0.980 & $0.4 \times 1.70$ & 26 & 0 \\
\hline C1-35 & 0.080 & 0.400 & 1.687 & 9.650 & $0.4 \times 1.45$ & 66 & 60 \\
\hline$C 2-35$ & 0.023 & 0.200 & 0.839 & 1.760 & $0.4 \times 1.86$ & 44 & 5 \\
\hline
\end{tabular}

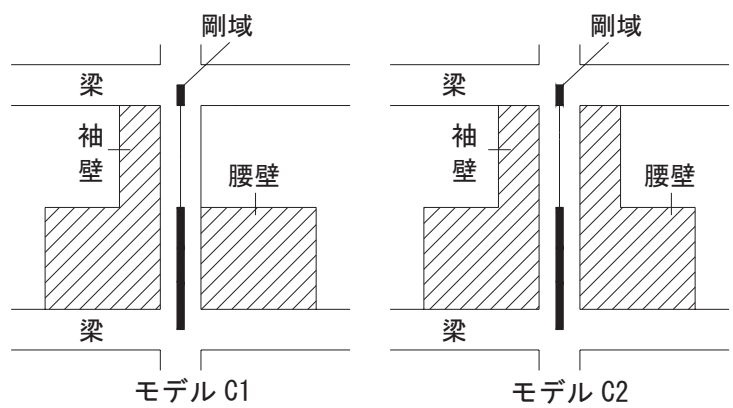

実建物のイメージ $\left(\mathrm{h}_{0} / \mathrm{D}=2.5\right.$ の場合 $)$

上記のように求めた各モデルの諸元を表 4 に示す。なお， $\mathrm{h}_{0} / \mathrm{D}=1.5$ と 3.5 の場合も, 図8におけるクリアスパンが異なるのみで, 他は $\mathrm{h}_{0} / \mathrm{D}$ $=2.5$ の場合と同様にして諸元を定めた。

\section{地震応答解析}

入力地震動として, 1995年神戸海洋気象台NS記録（以下JMA）お よび1978年東北大学NS記録（以下TOH）の地動レベルを最大速度 20 $\sim 70 \mathrm{~cm} / \mathrm{s}$ の範囲（一部 $45 \sim 95 \mathrm{~cm} / \mathrm{s}$ の範囲）で $5 \mathrm{~cm} / \mathrm{s}$ 刻みで変化させた 解析を行った。例として, 最大速度 $50 \mathrm{~cm} / \mathrm{s}$ の場合の加速度応答スペ クトルを図9に示す。

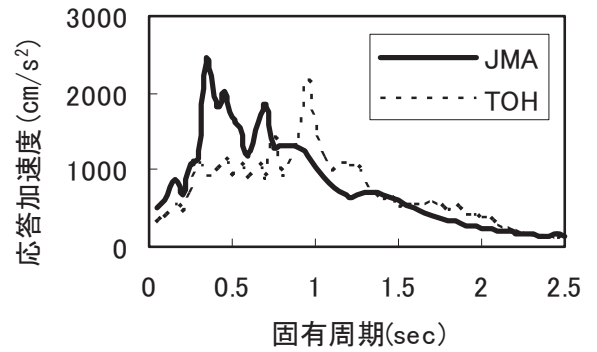

図 9 加速度応答スペクトル（最大速度 $50 \mathrm{~cm} / \mathrm{s}$ )

解析における減衰は初期剛性比例型とし, 減衰定数を $1 \%$ とした。 復元力モデルの繰り返し応答に対寸る履歴特性には，付着破壊し た場合には文献16)における「曲げ型」を，せん断破壊した場合には 同じく「せん断型」をそれぞれ用いた。これらの履歴特性は武田ス リップモデルを基本とし，「曲げ型」では，正負方向において各々 の方向での過去の最大変形点を指向するが，「せん断型」では，ど ちらの方向においても，正負方向での過去の最大変形点を指向する ものである。

\section{解析結果}

解析の結果, 寸べての場合で1層の応答変形が最大となったため, 以下では1層についてのみ論じる。

(a) $h_{0} / D=2.5$

$\mathrm{JMA} 35 \mathrm{~cm} / \mathrm{s}$ に対するモデル $\mathrm{C} 0$ とモデル $\mathrm{C} 1$ のベースシヤー係数-層 間変形角関係を図10に示す。柱のみのモデルC 0 では，変形が第2折 れ点を超えて最大変形が $0.65 \%$ となった。一方, 袖壁を付加したモ デルC1では, 変形が第2折れ点以前にとどまって最大変形が $0.25 \% に$ 抑えられた。袖壁付加による最大強度と剛性の上昇によって, 変形 が第2折れ点を超えなかったと考えられる。つまり, 袖壁付加が有利 に作用したといえる。 


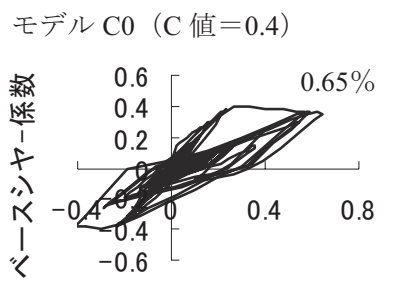

層間変形角 $(\%)$
モデル $\mathrm{C} 1 （ \mathrm{C}$ 值 $=0.4 \times 1.40)$

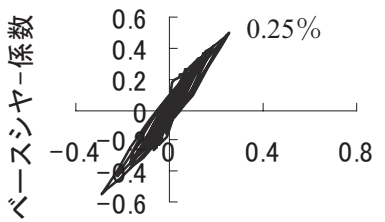

層間変形角 $(\%)$

$$
\text { JMA }(35 \mathrm{~cm} / \mathrm{s})
$$

図 10 荷重変形関係

袖壁の枚数が異なる各モデルに対する地動最大速度と崩壊危険率 の関係を図11(a)に示す。ここで，崩壊危険率とは崩壊変形に対する 最大変形の割合である。同一の地動速度に対して崩壊危険率が低い ほど建物の耐震性能が良いことを示している。また, 図中の〉は第2 折れ点時の崩壊危険率を示す。図中の点線については後述する。

JMAとTOHのいずれに対しても, モデル $\mathrm{C} 1$ はモデルC 0 より崩壊危 険率が小さく, モデルC 2 はモデル $\mathrm{C} 1$ よりさらに崩壊危険率が小さく なった。つまり, モデル 0 , モデル $\mathrm{C} 1$, モデル $\mathrm{C} 2$ の順に（袖壁の枚 数が増えるにつれて），耐震性能が上昇した。これは，袖壁を増や すほど，崩壊変形の減少より最大強度と剛性の増加の影響が大きか ったためと考えられる。ただし，モデルC1とモデルC2では第2折れ 点以後の荷重低下が急激であるため, 第2折れ点を超えた後急激に崩 壞危険率が上昇している（モデルC 0 では耐力低下が急でないため， 第2折れ点を超えた後の崩壊危険率の上昇が緩やかである)。つまり， せん断破壊する場合, 第2折れ点を超えるか否かが重要であることに， 注意が必要である。

ここで，モデル $\mathrm{C} 0$ は付着破壊であるが，実験結果（図2）からわ かるように, 層間変形角 $1 \%$ 程度でせん断破壊した後に比較的小さい 変形で崩壊しており，せん断型に近い挙動であった。つまり，付着 破壊とはいえせん断型に近い挙動を示す柱に袖壁が付く場合, 袖壁 の枚数が増えるほど（袖壁の量が増えるほど）耐震性が向上すると いえる。

(b) $h_{0} / D=1.5$

地動最大速度と崩壊危険率の関係を図11(b)に示す。JMAと TOHの いずれに対しても，ほとんどの領域で，モデルC1の崩壊危険率はモ デルC0より小さくなった。 $\mathrm{h}_{0} / \mathrm{D}=1.5$ の柱は両者ともせん断型であり， 上記と同様に，袖壁付加による最大強度と剛性の上昇により袖壁付 加が有利に作用したといえる。

(c) $h_{0} / D=3.5$

地動最大速度と崩壊危険率の関係を図11(c)に示す。ここで，壁の ないC0-35は実験で崩壊しなかったため検討から除外し, 袖壁が1枚 および2枚の場合を比較する。付着破壊型のモデルC1では，対応す る試験体の崩壊層間変形角が $9.65 \%$ と大きいので，最大変形が第2折 れ点を超えても変形は急には増加しなかった。一方, せん断破壊型 のモデルC2では, 地動速度が小さいうちは崩壊危険率が小さかった が, 地動速度が大きくなると第2折れ点を超えて崩壊危険率が急増し た。結果として崩壊危険率は，地動速度が大きくなっていくと，あ るところからC1 $2 \mathrm{C} 2$ の大小関係が逆転した。 $\mathrm{h}_{0} / \mathrm{D}=3.5$ ではモデル C1が付着型，モデルC2がせん断型であったが，この場合には袖壁の 付加は必ずしも有利であるとはいえない。
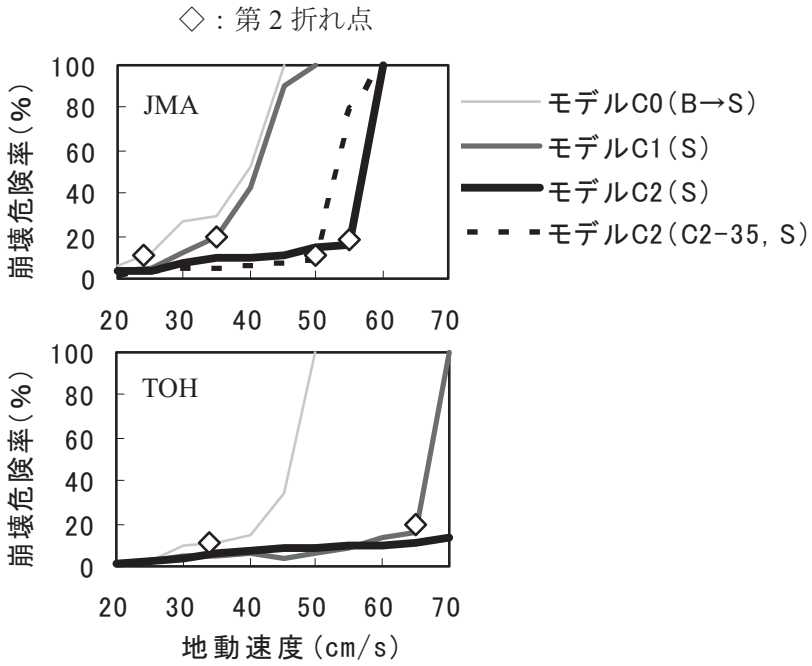

(a) $\mathrm{h}_{0} / \mathrm{D}=2.5$
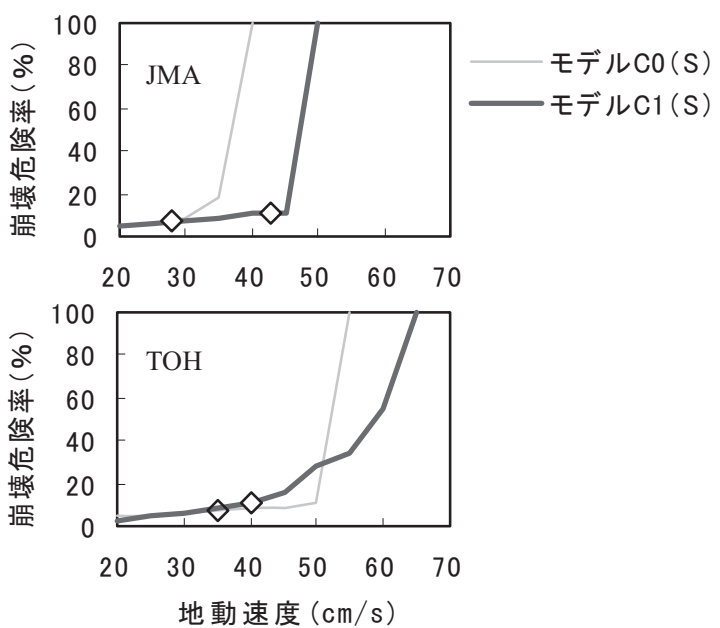

(b) $\mathrm{h}_{0} / \mathrm{D}=1.5$
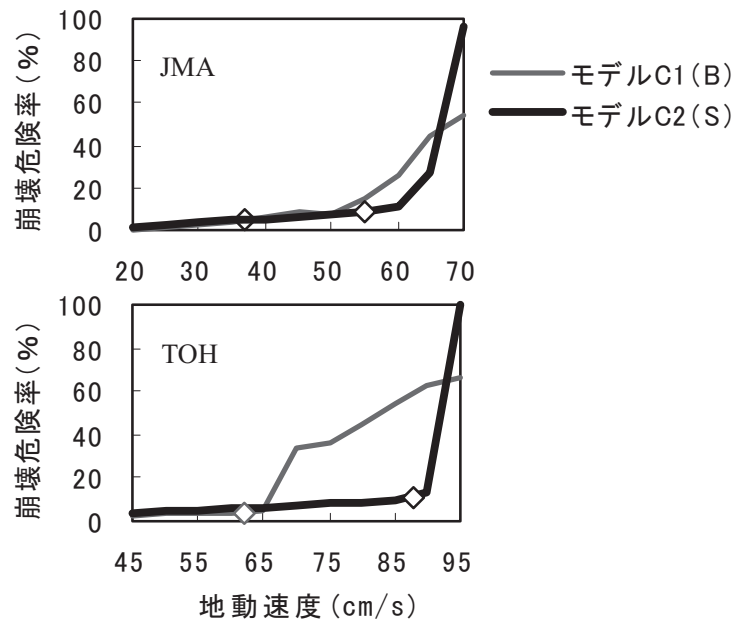

(c) $\mathrm{h}_{0} / \mathrm{D}=3.5$

図 11 袖壁の有無による崩壊危険率の違い 


\section{袖壁付加による反曲点高さの変化を考慮した検討}

上記の解析では反曲点高さをクリアスパンの中央と考えてスケル トンカーブを設定したが，袖壁付き柱が上下の層に連続する場合に は反曲点高さが多少変化することになる。そこで, 袖壁2枚のモデル C2について反曲点高さの変化を考慮した解析を行った。ここで, 袖 壁1枚のモデルC1では反曲点高さの変化は小さいと考えて検討は行 わなかった。 $\mathrm{h}_{0} / \mathrm{D}=2.5$ のテデル $\mathrm{C} 2$ にいて, 反曲点の影響を考慮し て,クリアスパンが本来の試験体のものより高い試験体を用いた。 つまり，スケルトンカーブをC2-35試験体を基にして定めた。これは 反曲点高さをクリアスパンの 0.70 倍としたものに相当する。なお, 最大強度はC0-25 と 2 - 35 の実験結果の比率に合わせて定めた。

JMAに対するC2-35を用いた場合の地動最大速度と崩壊危険率の 関係を, 図11(a)に点線で示寸。反曲点の変動を考慮したC2-35 と無 視したC2-25（図11(a)中の太線）を比較すると，ほぼ同様の傾向を 示している。つまり, 反曲点の変動を考慮した場合でも袖壁付加が 耐震上有利であるという結果は同じであった。

\section{解析結果のまとめ}

クリアスパンが比較的短く，柱のみの場合の破壊モードがせん断 型，あるいは付着型ではあるが最大強度後せん断的な挙動を示寸柱 に対しては，袖壁付加は有利といえる $\left(\mathrm{h}_{0} / \mathrm{D}=1.5,2.5\right)$ 。

一方，クリアスパンが比較的長く破壊モードが付着型の柱に対し て，袖壁を増やすことによって破壊モードがせん断型に変化する場 合には，袖壁付加は必ずしも有利とはいえない（$\left(\mathrm{h}_{0} / \mathrm{D}=3.5: \mathrm{C} 1-35\right.$ とC2-35の比較）。壁が増えてせん断型となる場合には最大強度が上 昇寸る分崩壊に対して有利である一方で, 崩壊変形が小さくなり, 最大強度後の荷重低下が急激である分崩壊に対して不利であるため, どちらの影響がより大きいかが不明瞭であるためである。

解析は行っていないが, クリアスパンが長く, 破壊モードが付着 型の柱に対して, 袖壁を付加しても破壊モードが変化しない場合に は, 袖壁付加によって最大強度と剛性が増大寸るため, 袖壁付加は 有利と思われる $\left(\mathrm{h}_{0} / \mathrm{D}=5.5\right)$ 。

以上より， $\mathrm{h}_{0} / \mathrm{D}=1.5 ， 2.5 ， 5.5$ のケースでは袖壁付加が有利とな り, $\mathrm{h}_{0} / \mathrm{D}=3.5$ の1ケースでは袖壁付加は必ずしも有利であるとは言 えない, という結果となった。総体的に見て袖壁付加は有利である といえる。

ただし, 以上の結果が限られた数の地震波での検討に基づくもの である点に，留意する必要がある。

\section{5. 結論}

本研究の範囲内で得られた結論を以下に示寸。

1) 袖壁が付くことによる最大強度の増加度合が同程度であるの に対して, 崩壊変形の低下度合はさまざまであるため, 実験結 果のみから袖壁付加の有利・不利について評価することは困難 である。そこで, 実験結果に基づく 3 層建物での地震応答解析 により，崩壊危険率を用いて耐震性能を検討した結果，1)クリ アスパンが比較的短くせん断破壊となる柱に対しては, 袖壁付 加は耐震性能上有利となる, 一方, 2)クリアスパンが比較的長 く袖壁を付加することによって付着破壊からせん断破壊に移 行する柱に対しては, 袖壁付加は必ずしも有利であるといえな
い,ことがわかった。以上より, 実験的研究を地震応答解析と 組み合わせることにより，3層建物に限定してではあるが，そ の耐震性能に対する袖壁の影響について評価できたと考えて いる。

2）袖壁付き柱のせん断終局強度の計算にQ $\mathrm{Su}_{\mathrm{S} 2}$ 式を用いる場合, シ ヤースパン比の下限值を 0.6 に修正するのが妥当である。

注

注1) 本研究では, 袖壁のない柱とそれに袖壁が付いた場合との直接比較によ り, 袖壁付加の有利・不利を判断する立場を採っている。しかし, 現実の 建物は複数の種類の柱から成っているので, その耐震性の良否を議論する ためには, より現実に近い場合を想定した検討が求められる。ここでのア プローチは，この点について限界を有していることを注記しておきたい。

\section{参考文献}

1) 東 洋一, 大久保全陸，江戸宏彰：静加力試験による腰壁，たれ壁，袖 壁付き鉄筋コンクリート柱の破壞性状と履歴曲線, 日本建築学会論文報 告集，第169号，pp. 165-168，1970.3

2) 大久保全陸：腰壁，たれ壁，袖壁付き鉄筋コンクリート骨組の剛性，強 度, および履歷特性に関する研究, 日本建築学会構造系論文集, 第 186 号, pp. 19-25, 1971.8

3) 東 洋一, 大久保全陸 : 鉄筋コンクリート袖壁付き柱の逆対称繰返し加 力実験（その1：せん断補强筋の少ない場合）, 日本建築学会大会学術 講演梗概集，pp. 1405-1406，1973.10

4) 東 洋一, 大久保全陸，藤又 康 : 鉄筋コンクリート袖壁付き柱の逆対 称繰返し加力実験 (その 2 : 壁厚の異なる場合, 袖壁を付加して補強す る場合）, 日本建築学会大会学術講演梗概集, pp. 1289-1290, 1974.10

5) 東 洋一, 大久保全陸 : 鉄筋コンクリート短柱の崩壊防止に関する総合 研究（その9 CWシリーズ: 袖壁付き柱の実験）, 日本建築学会大会学 術講演梗概集, C-2, pp. 1305-1306, 1974.10

6) 野村設郎，佐藤和英，座間奨和，山田隆久：たれ壁，袖壁，腰壁を有す る鉄筋コンクリート構造物の弾塑性性状, 日本建築学会関東支部研究報 告集, pp. 165-168, 1980

7) 原嶋幸一, 西川孝夫 : 袖壁付き柱の剛性と而力の組み合わせと骨組の耐 震性状の関係，日本建築学会関東支部研究報告集，pp. 141-144，1986

8）金 紅日, 芳村 学, 李 霓: 二次壁が付く鉄筋コンクリート柱の崩壊 挙動に関する研究, 日本建築学会関東支部研究発表会, 第76回研究報告 集I, pp. 177-180，2005

9) STニューテック研究会: 既存鉄筋コンクリート造建築物の耐震診断プロ グラム SCREEN-1.2 Ver.3.0, pp. 3-45-3-48, 2002

10）大宮 幸, 松浦康人, 香取慶一, 林 静雄: 袖壁付き柱の破壊形式を考 慮したせん断終局強度に関する実験および考察, 日本建築学会構造系論 文集，第553号，pp. 81-88，2002.5

11) 保木和明, 芳村 学: 主筋に丸鋼を用いた鉄筋コンクリート柱の付着性 状，日本建築学会大会学術講演梗概集， C-2, pp. 309-310, 2007.9

12）日本建築センター: 中高層壁式ラーメン鉄筋コンクリート造設計施工指 針・同解説，pp. $51 ， 1987$

13）小室達也, 広沢雅也, 瀧澤正明, 赤井裕史: 大変形下におけるRC造袖 壁付柱の耐震性能に対する帯筋比や構造スリットの影響に関する実験 的研究, コンクリート工学論文集, 第15 巻 第1号, pp. 69-80, 2004.1

14）高橋 仁, 広沢雅也, 清水 泰, 中沢 雅 : 鉄筋コンクリート短柱の崩 壊防止に関する総合研究（その46：NS2シリーズ実験結果の検討），日 本建築学会大会学術講演梗概集, pp. 1503-1504, 1977.10

15) 河本裕行, 江崎文也, 田中 睦: 主筋をアンボンド高強度鉄筋としたRC 短柱の履歴性状, コンクリート工学年次論文集, 第 27 巻 第 2 号, pp. 289-294, 2005

16）芳村 学, 上野裕美子, 中村孝也 : 既存低層鉄筋コンクリート建物のIs 值と倒壊の関倸，日本建築学会構造系論文集，第587号，pp. 197-204， 2005.1 